\title{
Capture Efficiency of Artificial Lures in Baited Lines for Mayan Octopus, Octopus maya, Fishery in Campeche, Mexico
}

\author{
UNAI MARKAIDA, IVÁN MÉNDEZ-LOEZA, and ALMENDRA RODRÍGUEZ-DOMÍNGUEZ
}

\begin{abstract}
Introduction
Fisheries which rely on the use of bait to lure the target resource usually produce little bycatch and demand more labor per unit catch than other fisheries, increasing economic and social benefits of their communities. However, dependence on bait involves many shortcomings. Bait availability (supply) and price may limit or preclude the full development of those fisheries (Shomura, 1977). In addition, the natural population of bait species may be severely impacted by their use, compromising the sustainability of these fisheries (Berkson and Shuster, 1999; Fahy, 2001; Gillett, 2011; IPNLF, 2012).
\end{abstract}

The authors are with the Laboratorio de Pesquerías Artesanales, El Colegio de la Frontera Sur (CONACyT), Av. Rancho Polígono 2A, Ciudad Industrial, Lerma, 24500 Campeche, Mexico. Corresponding author is Unai Markaida (umarkaida@ecosur.mx).

doi: https://doi.org/10.7755/MFR.81.1.3

ABSTRACT-The Mayan octopus, Octopus maya, fishery from the Campeche Bank is the largest octopus fishery in the Americas and one of the largest worldwide. This fishery uses a large quantity of crabs, Brachyura, as bait, and these crustacean populations are heavily impacted. To investigate alternative lures we examined the efficacy of various artificial lures ranging from plastic crabs to jigs baited with fish during the 2012 and 2013 seasons. Artificial PVC "crab" lures showed the best yields. However, their performance was less effective than natural crab in all cases. A simple simulation showed that using these lures, harvests would decrease by 42-44\% compared to using natural crab. We suggest the use of PVC crab combined with an organic compound that releases an attractive scent for octopus in further experiments.
Requirements for Marine Stewardship Council certification to minimize impacts on ecosystems are a serious constraint to certifying bait fisheries (Goyert et al., 2010). Introduction of exotic baits also can carry undesirable ecological and social impacts (Gillett, 2011). Additionally, some baits such as crabs, Brachyura, may themselves be taken with baited devices (Dellinger et al., 2016), and this may in turn impact or harm other fisheries. These shortcomings are also documented in octopus fisheries using baits. For example, Japanese ghost crabs, Macrophthalmus japonicus, used as bait in traps for Octopus minor in the Republic of Korea must be imported from China (Kim et al., 2015).

The Mayan octopus, Octopus maya, fishery on Mexico's Campeche Bank with annual landings over $15,000 \mathrm{t}$ is the largest octopus fishery in the Americas and one of the largest worldwide (FAO, 2018). This fishery employs lines baited with various crab species such as Florida stone crab, Menippe mercenaria; longnose spider crab, Libinia dubia; and blue crab, Callinectes spp., among others. This fishing method is considered to be sustainable regarding the octopus, as no spawning females, which stop feeding, are taken (Markaida et al., 2017). However, this fishery consumes a vast quantity of crabs, whose populations are negatively impacted, a fact noticed long ago (Solís-Ramírez, 1998; SolísRamírez et al., 1999; Carmona-Osalde and Rodríguez-Serna, 2012).

Stone crab is the main bait used in the octopus fishery in Lerma and Campeche, despite its express prohibition by both stone crab and octopus regulations (DOF, 2016a,b). A local commercial fishery harvests 16 annual tons of crab claws using traps. Additionally, it is taken illegally by skin divers.

Our limited data from six octopus fishermen during the 2012 and 2013 seasons estimated that each fisherman used 145 dozen $(174 \mathrm{~kg})$ declawed stone crabs per season (110 days) as bait. A rough estimate from a conservative figure of 700 fishermen in Lerma and Campeche would use $122 \mathrm{t}$ of declawed crabs per season. This is a far larger amount than the official catch of stone crab as suggested by claw landings.

If the octopus fishery employs 10,000 fishermen in all the Yucatan peninsula, bait use would be $900 \mathrm{t}$ of crabs per year, which represents half of all combined crab species (mainly blue crabs) landings in the Yucatan peninsula in those years (CONAPESCA, 2017). Crabs are a particularly expensive bait that may comprise half of the total daily costs involved in the fishery (see below). Use of crabs is a current concern in the management plan of this fishery (DOF, 2014) and it might constrain its desirable future certification.

Several discrete experiments have been worked out to try to substitute plastic crabs for natural crabs in this fishery. Clay pots "nummarellas" and collapsible traps have also been tested, but with no further follow up (SolísRamírez, 1998; Solís-Ramírez et al., 1999). Most experimental octopus fishing worldwide has been done using baited traps or artificial habitats (Barry et al., 2010; Rudershausen, 2013). To our knowledge, the only bait substitution experiment with fishing lines was performed in the giant Pacific octopus, 


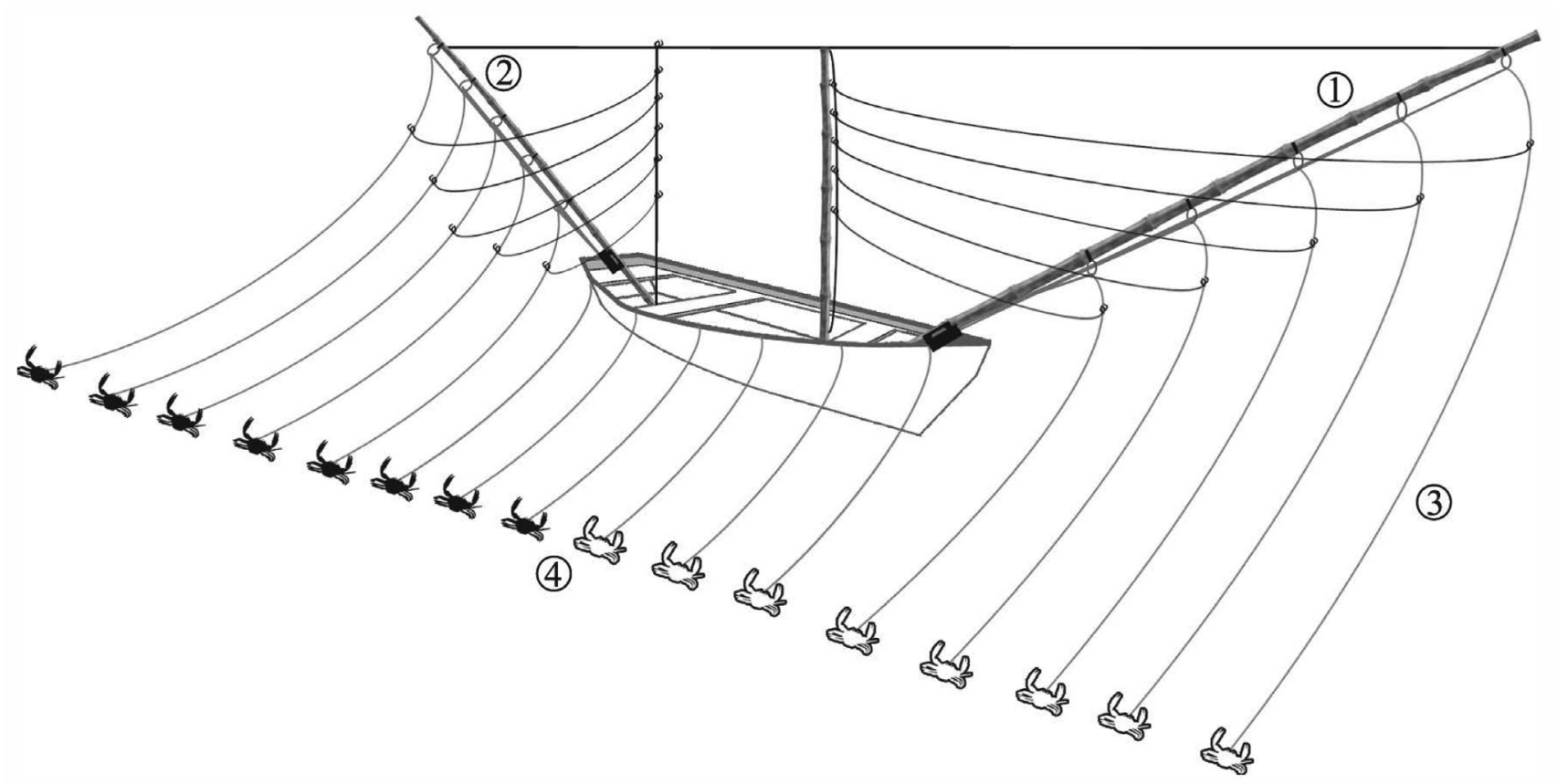

Figure 1.- Simplified model of an open boat showing fishing lines for Octopus maya in Campeche, starboard view: 1) bow fishing pole, 2) stern fishing pole, 3 ) fishing lines, 4) terminal tackle (detailed view shown in Figure 2). Half of the fishing lines were baited with natural crabs, the other half with artificial lures.

Enteroctopus dofleini, fishery from the Republic of Korea. In that successful test, artificial lures resembling crustaceans were more effective than the traditional pork skin used as bait (An and Arimoto, 2007). Given the large costs involved in using crabs for bait and the impact on their natural populations, this study sought to determine the feasibility of substituting artificial lures in lieu of fresh crabs in the Campeche octopus fishery.

\section{Materials and Methods}

Fishing with baited lines in the $O c$ topus maya, fishery at Campeche is performed from small open boats $(\sim 25$ feet length with $\sim 60 \mathrm{HP}$ outboard engines) drifting by wind or current. Typically, 4-7 fishing lines are set in the $6 \mathrm{~m}$ outboard portion on two long bamboo poles (called jimbas) fixed to the bow and stern. Additionally three to six lines are set in the leeward gunwale (Fig. 1). Fishing lines are made of nylon monofilament. Terminal tackle bears a $200 \mathrm{~g}$ lead sinker and the bait. One or two crabs are tied to the end of each line through a polypropylene line. A treble hook (size $1 / 0$ or $2 / 0$ ) is frequently added at the end of the tackle to prevent octopuses from escaping. A small float made of PVC foam keeps the treble hook from snagging on the bottom (Fig. 2).

A variety of lures resembling crabs (used for sport fishing) were tested as bait in this study as substitutes for natural crabs. The Berkley® Gulp Saltwater Rig Peeler $\mathrm{Crab}^{1}$ is an example of a soft lure made with natural ingredients which releases a strong scent. The "Fishing crab runner" is a hard plastic trolling lure with a treble hook. Both are used in sportfishing to catch fish (Fig. 3A, B). We also experimented with soft PVC crabs of two different sizes: Small (40 $\mathrm{mm}$ carapace width $(\mathrm{CW})$ red color crabs and large ( $81 \mathrm{~mm} \mathrm{CW}$ ) orange crabs (Fig. 3D, E).

${ }^{1}$ Mention of trade names or commercial firms is for identification purposes only and does not imply endorsement by the National Marine Fisheries Services, NOAA.
Hooked and baited tablets, which crawl over the bottom for octopus, have been traditionally used in the Mediterranean Sea and Japanese waters (Biagi, 1997; Yajima and Mitsugi, 1975). We used several modern commercial versions (Cal, 2011). The octopus jig with four hooks by Evia ${ }^{\circledR}$ has barbless hooks $17.9 \mathrm{~mm}$ wide (Fig. 3C). Discarded heads of finfish, such as white grunt, Haemulon plumierii; yellowfin mojarra, Gerres cinereus; or seatrout, Cynoscion sp., were set as baits. Similar octopus jigs with two hooks by Evia ${ }^{\circledR}$ has a soft PVC crab of both sizes mentioned above: Small PVC crabs are mounted on jigs with two $22.6 \mathrm{~mm}$ wide hooks, while large PVC crabs are set on jigs with 24.5 mm hooks (Fig. 3F, G).

These lures were set in the gear in the same way as are crabs (Fig. 2). Half of the fishing lines (five from a pole plus three from half of the gunwale) were baited with artificial lures, while the other half were set with natural crabs (Fig. 1). Declawed 
A

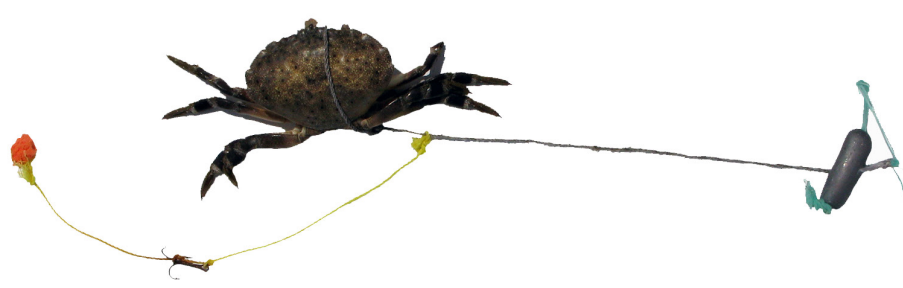

B
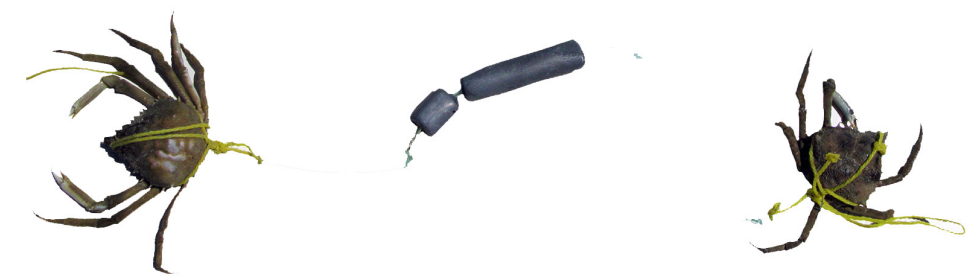

C
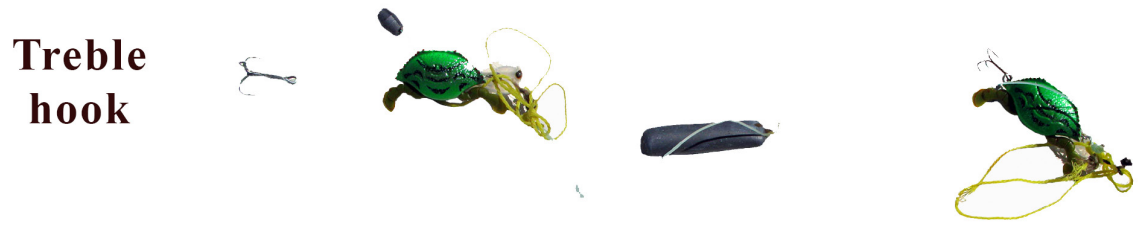

D

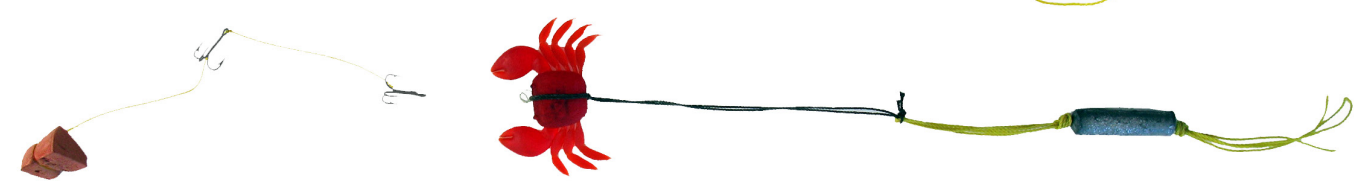

$\mathbf{E}$

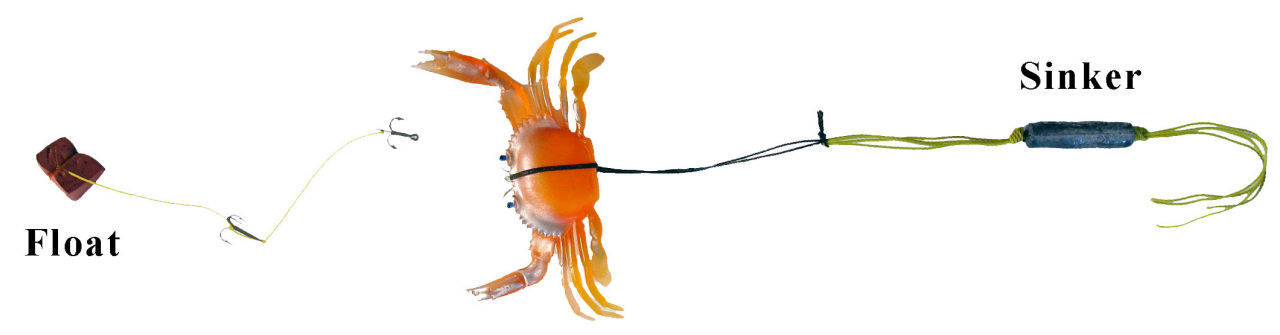

Figure 2.-Terminal tackle of the fishing gear for Octopus maya showing the sinker, bait, treble hooks, and float: A=arrangement of single bait, stone crab, Menippe mercenaria; $\mathrm{B}=$ double bait arrangement for spider crab, Libinia dubia. Selected examples of artificial baits settings: C=double arrangement for crab runner lure; $\mathrm{D}=$ single arrangement for small $\mathrm{PVC}$ crab; and $\mathrm{E}=$ single arrangement for large $\mathrm{PVC}$ crab.

local stone crab, Menippe mercenaria (30-80 $\mathrm{mm} \mathrm{CW}$, was used as natural bait. However, during the first two tests of 2012, warrior swimming crab, Callinectes bellicosus, imported from Chiapas, on the Mexican Pacific coast, was also used.

Experiments were performed in shallow waters (5-9 $\mathrm{m}$ depth) about 0.5-23 $\mathrm{km}$ off Lerma, Campeche, during two consecutive octopus fishing seasons (August-mid-December). Fishing operations typically started at 7 am and ended between 11 am and $1 \mathrm{pm}$.

Each day a single type of lure (treatment) was tested for fishing perfor- mance against the natural crabs in a single boat. In 2012, 37 fishing trips were made, from 20 September to 13 December. All the lures described (Fig. 3A-C and F-G; totaling five different treatments), except free PVC crabs, were used in different segments of this season. In 2013, 40 trips were made between 20 August and 4 October. That season we focused on the PVC crabs, employing both sizes mounted on jigs or set free (without jigs) (Fig. 3D-G; four different treatments).

All octopus taken were weighed to the nearest gram to obtain body weight
(BW) and measured for mantle length (ML) to the nearest mm. Sex and maturity were assigned upon examination of reproductive organs following a scale of four maturity stages for each sex: immature, maturing, mature, and spent (Markaida et al., 2017).

CPUE for each lure type and the corresponding natural baits were computed as the number of octopus caught by line in each fishing day. Another CPUE was calculated as the octopus weight ( $\mathrm{g}$ ) by line by fishing day. Both CPUE estimates were averaged for each lure type. Comparison of CPUE between natural baits vs. lures in each 


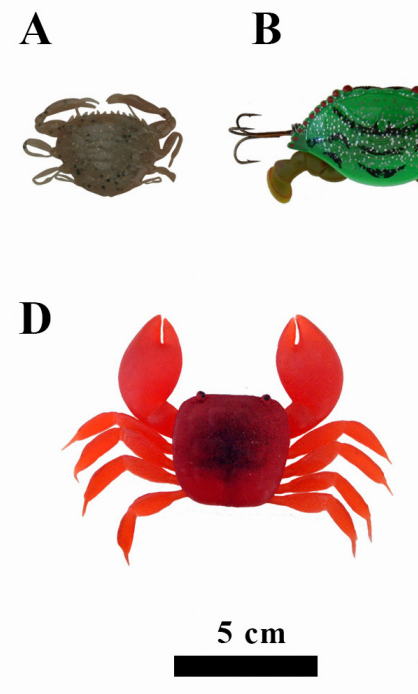

F

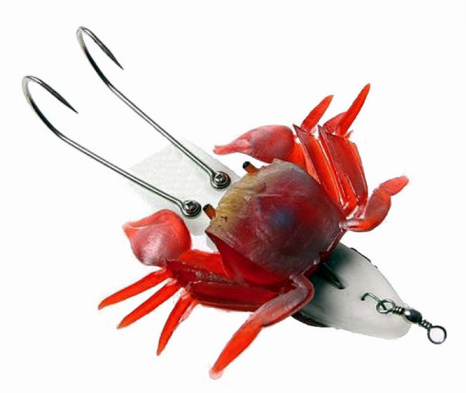

C

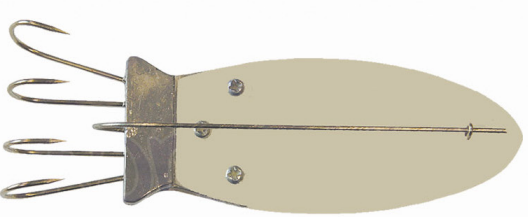

$\mathbf{E}$

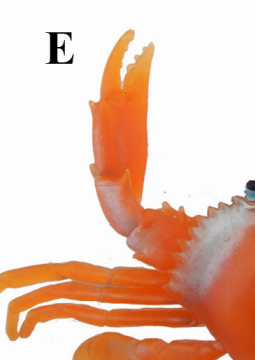

G

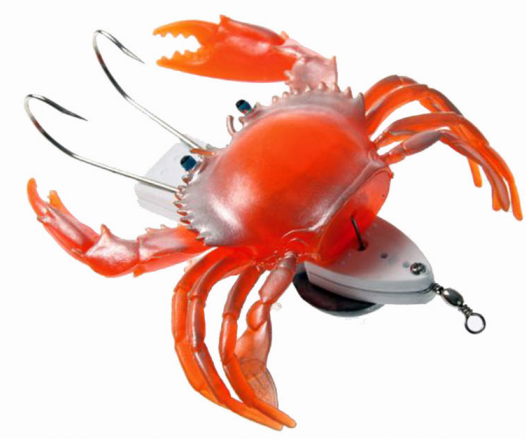

Figure 3.-Artificial lures used in the fishing lines for Octopus maya in this study: $A=$ Berkley ${ }^{\circledR}$ Gulp Saltwater Rig Peeler $\mathrm{Crab}$; $\mathrm{B}=$ crab runner; $\mathrm{C}=$ octopus jig with four hooks by Evia ${ }^{R} ; \mathrm{D}=$ small PVC crab; $\mathrm{E}=$ large $\mathrm{PVC}$ crab; $\mathrm{F}=$ octopus jig with two hooks by Evia ${ }^{\circledR}$ with small PVC crab; and $\mathrm{G}=$ with large PVC crab.

period was performed using a nonparametric Mann-Whitney U test.

During the 2013 season, the number of octopus that were brought to the surface but escaped was recorded. In addition, the number of octopus taken in the gear hooks was also recorded. The percentage of escaped octopuses and taken octopuses were calculated in each case, in relation to all octopuses that surfaced in the lines.

There is great concern about the impact of introducing new gear types in this fishery. Any possible selective effect on octopus attributes such as sex, size, or maturity stage by the use of artificial lures was assessed by a comparison with catches from natural crab baited lines. The Chi-square goodness of fit test was used to test the null hypothesis that sex ratio was equal between individuals taken by natural bait and those taken by artificial lures. It was also used to test the null hypothesis that observed frequencies of maturity stage in each sex were equal by fishing gear.

A Kolmogorov-Smirnov (K-S) goodness of fit test was employed to compare the distributions of octopus BW taken by fishing gear, considering sex and maturity stage. The K-S test was performed by computing the maximum distance between the cumulative distributions of both samples.

A notebook containing daily catch and fishing costs of six fishermen during 2012 and 2013 seasons was ana- lyzed (110 days each season). These data contain daily fishing costs (bait and fuel) and catch value in Mexican pesos (MXN). Daily gain for each fisherman was calculated subtracting the costs to the value of the catch. A hypothetical daily catch value using the best performing artificial lures was estimated by dividing the daily catch value by the ratio expressed as the mean CPUE obtained by natural crabs to that taken by the lure. A hypothetical daily gain was calculated by subtracting the fuel cost and assuming bait cost as null.

\section{Results}

The Berkley ${ }^{\circledR}$ Gulp Saltwater Rig Peeler Crab did not catch any octopus. This lure was not considered in further data analysis. During 2012 we caught 363 octopuses over 37 days, and in 2013 we caught 1,260 octopuses over 48 days. Lines baited with stone crabs and blue crabs did not differ statistically in their octopus catch by number (1.9 octopus/line) or by weight $(1,360$ and $1,285 \mathrm{~g} /$ line, respectively) (U test, $\mathrm{P}>0.05)$.

Octopus numbers taken by lines baited with natural crabs exceeded those taken with artificial lures by more than threefold in 2012 and by more than double in 2013, both by number and by weight (Table 1). Natural crabs captured more octopus by number and by weight per line in almost all days. During only five fishing days in 2012 did the catch rates by number equal both types of gear. In only three of the fishing days did artificial lures catch more octopuses than natural crabs, and in only five of the fishing days did artificial lures yield more octopus weight per line than natural crabs.

In 2012, mean CPUE for natural baits ranged from 0.6 to 2.3 octopuses per line (number/line) and 608-1,572 $\mathrm{g} /$ line, while that for artificial baits were from 0.16 to 0.6 number/line and 168-433 g/line, respectively. CPUE for natural baits were statistically larger (2.4 to 4 times greater) than for any kind of lure (Fig. 4A,C; $\mathrm{U}$ test, $P<$ 0.05). Only for jigs with small PVC 
crabs was this difference not statistically significant for both kinds of CPUE ( $\mathrm{U}=15, \mathrm{U}=14, P>0.05)$, even when these lures caught less than half the octopus that natural crabs did.

Mean CPUEs during the 2013 season were larger than in 2012. They ranged from 2.3 to 3.4 number/line and from 1,344 to $2,239 \mathrm{~g} /$ line in natural baits, while CPUE for artificial lures were 0.4-1.9 number/line and 364-1,294 g/line, respectively. Comparison between the yield presented by each type of artificial lure versus natural crabs showed that the latter yielded larger CPUE in all cases (Fig. 4B, D; U test, $P<0.05$ ). Small PVC crabs showed the best performance among lures, although natural crabs still doubled their CPUE (both by number and by weight): 1.75 times more than small PVC crabs set on jigs and two times more than when set free (Fig. 4B, D).

The percentage of octopus that left the PVC crabs when brought to the surface and escaped during 2013 varied according to lure size. Large PVC crabs had larger escape percentages when set on jigs $(42 \%)$ or free $(30 \%)$ than small PVC crabs $(20 \%$ on jigs, $14 \%$ free). Escapement from natural baits was always much lower, usually $\leq 6 \%$. Only $10 \%$ of octopus taken by jigs with large PVC crabs were entangled in jig hooks, while $42 \%$ of those taken by free large crabs were taken with the treble hooks. Slightly more than half $(52-58 \%)$ of octopus taken by lures with small PVC crabs (on jigs or free) were taken with their hooks.

Octopus taken by artificial lures and natural baits were equal by sex and maturity stage composition, as well as by BW (Fig. 5). Overall female:male ratio was 0.79 and this ratio did not vary with octopus caught by lures or among those taken by bait $\left(\chi^{2}=0.21\right.$; d.f. $=1 ; P>0.05)$. Among females, $85 \%$ were immature, $13 \%$ maturing, and $1.5 \%$ mature, and this distribution did not change with fishing gear $\left(\chi^{2}=\right.$ 2.04 ; d.f. $=2 ; P>0.05)$. Almost half of males were mature (48\%), 30\% maturing, and 22\% immature. Likewise, this distribution did not change by fishing gear $\left(\chi^{2}=1.39\right.$; d.f. $\left.=2 ; P>0.05\right)$. No

Table 1.-Summary of the experimental fishery with lures for Octopus maya: Octopus number (N) and body weight (BW in kg) caught by lines baited with artificial lures vs. natural crabs during 2012 and 2013 fishing seasons. Natural crab used were stone crab (S) and blue crab (B). The Berkley® Gulp Saltwater Rig Peeler Crab was not included due to null performance.

\begin{tabular}{|c|c|c|c|c|c|c|c|}
\hline \multirow[b]{2}{*}{ Lure type } & \multirow[b]{2}{*}{ Crab } & \multirow[b]{2}{*}{ Date } & \multirow[b]{2}{*}{ Days } & \multicolumn{2}{|c|}{ Artificial lure } & \multicolumn{2}{|c|}{ Natural bait } \\
\hline & & & & $\mathrm{N}$ & BW & $\mathrm{N}$ & BW \\
\hline \multicolumn{8}{|l|}{2012} \\
\hline Crab runner & S, B & Sept $20-$ Oct 12 & 14 & 43 & 30.4 & 162 & 110.1 \\
\hline Jig four hooks & S, B & Oct 25-Nov 9 & 8 & 16 & 10.9 & 46 & 35.5 \\
\hline Jig small crab & S & Nov 13-Dec 5 & 8 & 16 & 14.1 & 40 & 38.8 \\
\hline \multirow[t]{2}{*}{ Jig large crab } & $S$ & Dec 6-13 & 7 & 8 & 8.3 & 32 & 29.8 \\
\hline & & & 37 & 83 & 63.7 & 280 & 214.2 \\
\hline \multicolumn{8}{|l|}{2013} \\
\hline Jig large crab & $\mathrm{s}$ & Aug 2-13 & 6 & 20 & 17.5 & 95 & 58.4 \\
\hline Free large crab & $\mathrm{s}$ & Aug 13-Sep 6 & 7 & 26 & 18.2 & 119 & 79.6 \\
\hline Jig small crab & $\mathrm{s}$ & Aug 20-23 & 4 & 31 & 20.7 & 54 & 35.8 \\
\hline \multirow[t]{2}{*}{ Free small crab } & $\mathrm{S}$ & Aug 26-Oct 4 & 31 & 289 & 163.5 & 626 & 354.2 \\
\hline & & & 48 & 366 & $\overline{219.9}$ & 894 & $\overline{528.0}$ \\
\hline Total & & & 85 & 449 & 283.6 & 1,174 & 742.2 \\
\hline
\end{tabular}

2012 2013

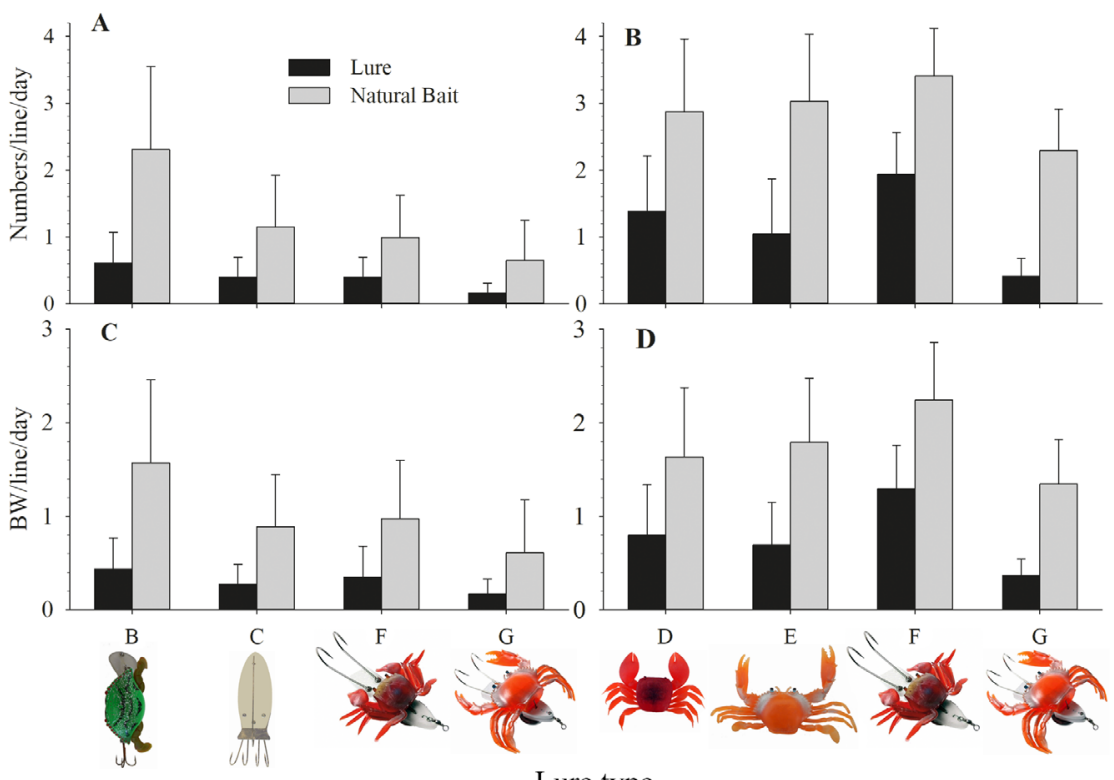

Lure type

Figure 4.- Mean catch per unit of effort $( \pm$ S.D.), measured as (A, B) daily octopus number caught per line and $(\mathrm{C}, \mathrm{D})$ daily octopus $\mathrm{kg}$ per line, for different artificial lures and their comparison with corresponding CPUE by lines baited with natural crabs for (A, C) 2012 and (B, D) 2013 at Lerma, Campeche. Lure types coded as in Fig. 3: B) crab runner, C) jig with four hooks, D) free small PVC crab, E) free large PVC crab, F) jig with small PVC crab, and G) jig with large PVC crab.

spent individuals were caught during the study (Fig. 5).

Although females averaged $634 \pm$ $257 \mathrm{~g} \mathrm{BW}$ and were smaller than males $(678 \pm 295 \mathrm{~g} \mathrm{BW})(\mathrm{K}-\mathrm{S}$ test, $\mathrm{D}=$ $0.07 ; P<0.05)$, this sexual difference was not found between octopus taken by the same kind of gear (K-S test, $P$
$>0.05)$. Otherwise, octopus BW distribution did not change between individuals taken by fishing gears for the same sex and maturity stage (K-S test; $P>0.05$; Fig. 5). Octopus under the minimum legal size of $110 \mathrm{~mm} \mathrm{ML}$ (DOF, 2014) represented $54 \%$ by number in both fishing gears. 


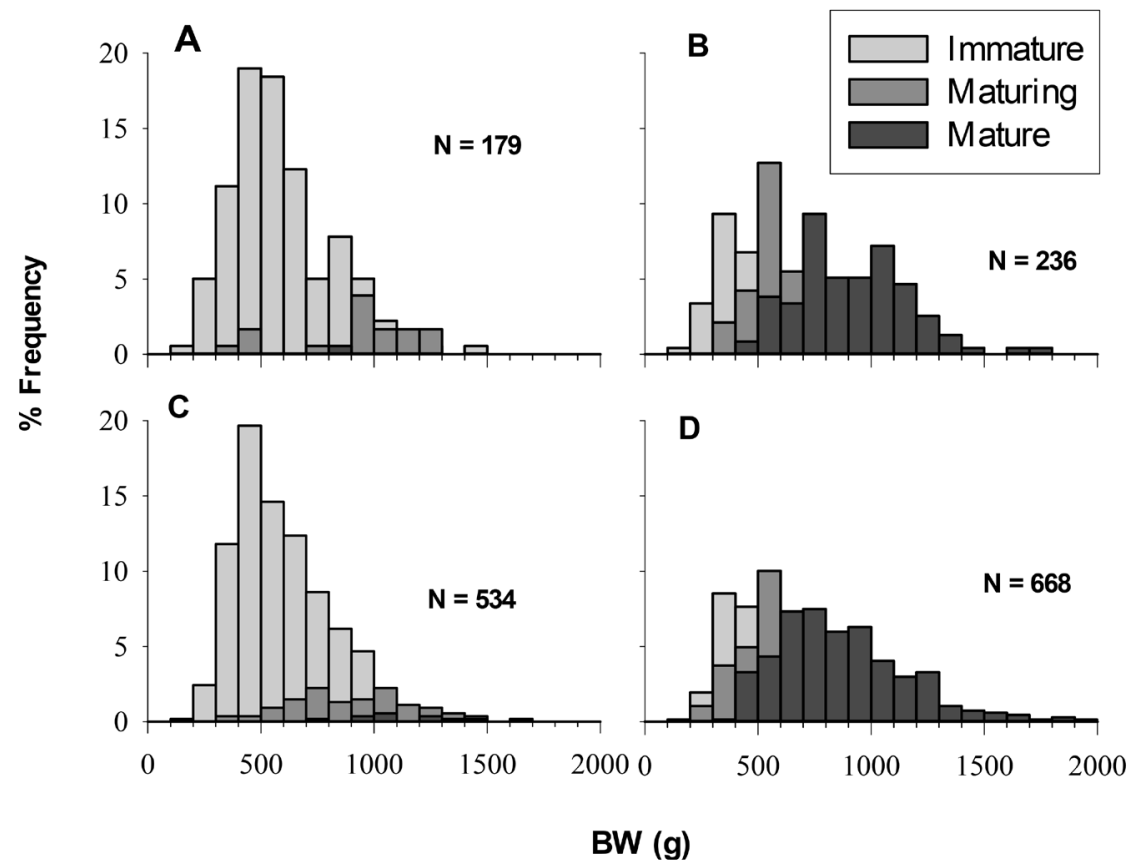

Figure 5.-Body weight (BW) frequency distribution of Octopus maya: (A, B) taken with all artificial lures pooled and (C, D) taken with natural baits; by sex (A, C) females; $(\mathrm{B}, \mathrm{D})$ males and by maturity stage.
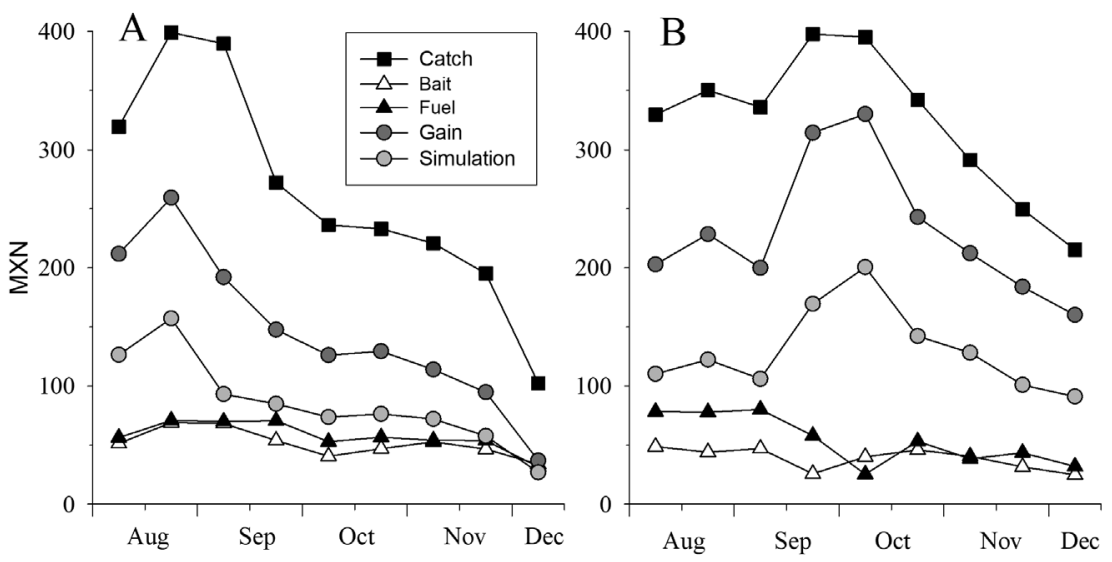

Month

Figure 6.-Biweekly evolution of daily values of octopus catch, bait and fuel, and gain and simulated gain in Mexican pesos (MXN) for the fishing seasons of (A) 2012 and (B) 2013.

Octopus daily catch value peaked in 2012 early in the season, while in 2013 it peaked in mid-season, reflecting a slight shift in catch stationarity (Fig. 6). Octopus price slightly increased to 23 pesos $/ \mathrm{kg}$ in 2013
(US $\$ 1.77 / \mathrm{kg}$ ), while costs (fuel and bait) slightly decreased (Fig. 6; Table 2). Bait costs equaled that of fuel cost for most of the season. The use of artificial lures during 2012 would save up to 5,772 pesos (US\$444)
Table 2.-Unitary and daily value of octopus catch, bait and fuel, and gain and simulated gain in Mexican pesos (MXN) for fishing seasons 2012 and 2013.

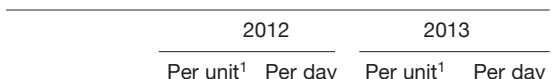

\begin{tabular}{lcrcr}
\hline US Dollar & 13.1 & & 12.7 & \\
Catch & 20 & 270 & 23 & 332 \\
Bait & $25-70$ & 52 & $25-70$ & 40 \\
Fuel & 11.7 & 57 & 10.8 & 55 \\
Gain & & 151 & & 238 \\
Simulated gain $^{2}$ & & 88 & & 134 \\
\hline
\end{tabular}

${ }^{1}$ Unitary prices for catch per $\mathrm{kg}$ of octopus, for bait per dozen or kg of crabs, for fuel per liter.

${ }^{2}$ Calculated as catch value divided by 1.75 and subtracting fuel cost.

in bait costs (52 pesos/day (US\$4)) during the season (111 days). However, when considering even their best performance (small PVC crabs set on jigs, which achieved a CPUE 1.75 times lower than that performed by natural crabs), a $42 \%$ decrease would result, from $151 \mathrm{MXN} /$ day (US\$11.62) to $88 \mathrm{MXN} /$ day (US\$6.77). In 2013 larger catches during the season coupled with reduced costs increased the gain to 238 MXN/day (US\$18.31). Again, simulation with artificial lures (134 MXN/ day (US\$10.31)) accounted for a $44 \%$ decrease (Table 2).

\section{Discussion}

Testing baited line performance in octopus catch is difficult as daily catches shows a high variability between boats, precluding any comparison between lines from different boats. Hence, experiments were carried out on the same vessel. With sixteen lines on a boat, trials were limited to one kind of lure each day. We determined $1.5 \mathrm{~m}$ between lines to be large enough to avoid octopus choosing between them. This procedure however precludes directly comparing the performance of different artificial lures as they were tested during different time periods with variable octopus availability. This is clearly shown for natural bait CPUE, which showed maximum values during the first 2 months of 2013, while they sharply decreased during the last months of 2012 (Fig. 4 ), reflecting the decline of octopus catches as the fishing season advances (Markaida et al., 2017). We con- 
sider that the best estimate of performance by an artificial lure would be the ratio between its CPUE to the correspondent natural bait CPUE. This ratio could be comparable between different lures.

The Berkley ${ }^{\circledR}$ Gulp Saltwater Rig Peeler Crab was readily consumed by the abundant puffers, Sphoeroides sp. and Lagocephalus sp., around the boat and it did not catch any octopus. This fact mitigates against the use of soft lures in the Octopus maya fishery. Crab runner lures were the only ones which produced some bycatch (nine puffers and three remora, Echeneis naucrates), as they are designed for sport fishing. Their treble hooks usually fill with sea grass or they snagged on the bottom, so this lure was unsuitable for octopus fishing.

The rest of the lures produced no bycatch. Octopus jigs set on the lines quickly slide over the soft bottom with their hooks right side up, in proper position. However, jigs with four barbless hooks showed the poorest performance amongst all lures when baited with finfish. Octopus catches greatly improved when similar jigs were baited with PVC crabs during 2012. This fact has encouraged us to focus on PVC crabs for the next fishing season, when small PVC crabs yielded larger CPUE than larger ones.

Large size PVC crabs showed high rates of octopus escapement ( $\geq 30 \%$ ) before retrieving the catch on board. This may be due to the fact that octopus have a maximum preferred size for prey. The use of treble hooks to prevent octopus escapement proved convenient as more than half of octopus are taken with them when used with small PVC crabs.

Octopus size, sex ratio, and maturity stage caught by both natural crabs and artificial lures were similar, so these methods did not demonstrate any differential discrimination. In both cases, mature males and immature females dominated the catch. No spent females and only a few mature ones were taken, confirming the beneficial selectivity of baited lines for the sustainability of the octopus fishery. However, octopus less than the legal size dominated catches, as previously found by Markaida et al. (2017), which is another serious concern in this fishery.

Yearly differences in octopus catches and fishing costs greatly affects the gain obtained by fishermen. Costs may vary due to different fuel demand driven by spatial changes in octopus biomass and by bait availability. Although the use of lures would avoid bait costs, even the most effective of them would undergo a $42-44 \%$ decrease in daily gain. Simulated daily gain in 2013 using lures was slightly lower than real gain from 2012 using crabs (Table 2), which might encourage the use of artificial lures in certain circumstances. However, it is unlikely that fishermen would accept a $42 \%$ reduction in their harvests as the octopus fishery has become the most profitable activity for them throughout the year. The most plausible way to promote the use of artificial lures in the octopus fishery would be to improve their performance.

Fishermen claim that live baits are more effective than fresh ones, and much more effective than artificial lures (Kumar et al., 2016). The effectiveness of bait seems to result from the combination of both the visual and chemical stimulus they send (Anraku et al., 2005). Further experiments with artificial lures in the Octopus maya fishery must consider the latter, perhaps combining the most successful lure, PVC crabs, with an organic compound that releases an attractive scent for octopus.

\section{Acknowledgments}

We are greatly indebted to Rubén Sánchez and octopus fishermen Francisco Deib "Rana", Alex Jah, and Ramón Méndez and his sons for their collaboration during this experiment. Fundación Produce Campeche A.C. supported this experiment through the project "Validation of an alternative to Mayan octopus fishing (Octopus maya) with baited lines in the municipality of Campeche." Two anonymous reviewers greatly improved this contribution through their criticism.

\section{Literature Cited}

An, Y. I., and T. Arimoto. 2007. Development of artificial bait for octopus drift line. J. Kor. Soc. Fish. Tech. 43(4):291-300 [In Kor., Engl. abstr.] (doi: https://doi.org/10.3796/ KSFT.2007.43.4.291)

Anraku, K., M. V. Archdale, K. Hatanaka, and T. Marui. 2005. Chemical stimuli and feeding behavior in octopus, Octopus vulgaris. Phuket Mar. Biol. Cent. Res. Bull. 66:221227.

Barry, P. D., S. L. Tamone, and D. A. Tallmon. 2010. Evaluation of the capture efficiency and size selectivity of four pot types in the prospective fishery for North Pacific giant octopus (Enteroctopus dofleini). Fish. Bull. 108(1):39-44

Berkson, J., and C. N. Shuster. 1999. The horseshoe crab: the battle for a true multipleuse resource. Fisheries 24(11):6-10 (doi: https://doi.org/10.1577/1548-8446(1999) 024<0006: THCTBF>2.0.CO;2).

Biagi, V. 1997. Polpi, seppie e "totani" nel mare di Piombino e dell'Isola d'Elba. 1st ed. Bandecchi e Vivaldi, Pontedera, 131 p. [In Italian].

Cal, J. M. 2011. Saltwater fishing lures guide, 1st ed., RC Ediciones, 190 p. [Ebook].

Carmona-Osalde, C., and M. Rodríguez-Serna. 2012. Reproductive aspects of the spider crab Libinia dubia under laboratory conditions. Hidrobiologica 22(1):58-61 (http://www.scielo.org.mx/pdf/hbio/v22n1/v22n1a8.pdf)

CONAPESCA. 2017. Anuario estadístico de acuacultura y pesca. Comisión Nacional de Acuacultura y Pesca. Mazatlán, México, 293 p. (https://www.conapesca.gob.mx/work/ sites/cona/dgppe/2017/ANUARIO_ESTADIS TICO_2017.pdf) (accessed January 2019).

Dellinger, A., J. Plotkin, B. Duncan, L. Robertson, T. Brady, and C. Kepley. 2016. A synthetic crustacean bait to stem forage fish depletion. Global Ecol. Conserv. 7:238-244 (doi https://doi.org/10.1016/j.gecco.2016.07.001).

DOF. 2014. Acuerdo por el que se da a conocer el Plan de Manejo Pesquero de pulpo (O. maya y O. vulgaris) del Golfo de México y Mar Caribe. Diario oficial de la federación 28-03-2014 (http://dof.gob.mx/nota detalle.php? codigo $=5338727 \&$ fecha $=28 / 03 / 2014$ ) (accessed January 2019).

2016a Norma Oficial Mexicana NOM-045-SAG/PESC-2015, Especificaciones para regular el aprovechamiento de la especie de cangrejo moro (Menippe mercenaria), en las aguas de jurisdicción federal del Estado de Campeche. Diario oficial de la federación 15-2-2016 (http://diariooficial.gob. $\mathrm{mx} /$ nota detalle.php? codigo $=5425628 \& \mathrm{fec}$ ha $=15 / 02 / 2016$ ) (accessed January 2019). 2016b. Norma Oficial Mexicana NOM008SAG/PESC2015 para ordenar el aprovechamiento de las especies de pulpo en las aguas de jurisdicción federal del Golfo de México y Mar Caribe. Diario oficial de la federación 13-4-2016 (http://diariooficial. gob.mx/nota_detalle.php?codigo $=5432972 \&$ fecha $=13 / 04 / 2016$ ) (accessed January 2019).

Fahy, E. 2001. Conflict between two inshore fisheries: for whelk (Buccinum undatum) and brown crab (Cancer pagurus) in the southwest Irish Sea. Hydrobiologia 465:73-83 (doi:.org/10.1023/A:101454925248).

FAO. 2018. Fisheries and aquaculture software. FishStatJ - software for fishery statistical time 
series. FAO Fish. and Aquacult. Dept. (http:// www.fao.org/fishery/statistics/software/fishstatj/en)(accessed January 2019).

Gillett, R. 2011. Replacing purse seining with pole-and-line fishing in the central and western Pacific: some aspects of the baitfish requirements. Mar. Pol. 35(2):148-154 (doi: https://doi.org/10.1016/j.marpol.2010.08. 013).

Goyert, W., R. Sagarin, and J. Annala. 2010. The promise and pitfalls of marine stewardship council certification: Maine lobster as a case study. Mar. Policy 34(5):1,1031,109 (doi: https://doi.org/10.1016/j.marpol.2010.03.010).

IPNLF. 2012. Ensuring sustainability of livebait fish. Int. Pole-and-Line Found., Lond., 57 p. (http://ipnlf.org/resources/ipnlf-documents/ document/technical-report-1-ensuring-sustainability-of-livebait-fish) (accessed January 2019).
Kim, S. H., K. H. Lee, S. W. Park, and D. G Lee. 2015. Study on the fishing performance of an alternative tubular-type pot for the common octopus, Octopus minor, in Korean coastal waters. Iran. J. Fish. Sci. 14(1):73-86 (http:// jifro.ir/article-1-1824-en.html).

Kumar, K. V. A., P. Pravin, and B. Meenakumari. 2016. Bait, bait loss, and depredation in pelagic longline fisheries-A review. Rev. Fish. Sci. Aquacult. 24:295-304 (doi: https://doi.or g/10.1080/23308249.2016.1162134).

Markaida, U., I. Méndez-Loeza, and M. Rosales-Raya. 2017. Seasonal and spatial trends of Mayan octopus, Octopus maya, population dynamics from Campeche, Mexico. J. Mar. Biol. Assoc. U.K. 97(8):1,6631,673 (doi: https://doi.org/10.1017/ S0025315416001132).

Rudershausen, P. J. 2013. Gear modifications for fishing octopus, Octopus vulgaris, on live-bottom and adjacent flat bottom hab- itats in coastal waters off North Carolina. Mar. Fish. Rev. 75(3):13-20 (doi: https://doi. org/10.7755/MFR.75.3.2)

Shomura, R. S. 1977. A summary of the tuna baitfish workshop. In R. S. Shomura (Editor), Collection of tuna baitfish papers, $\mathrm{p}$ 1-5. U.S. Dep. Commer., NOAA Tech. Rep. NMFS Circ. 408.

Solís-Ramírez, M. J. 1998. Aspectos biológicos del pulpo Octopus maya Voss y Solís. B. Sc. Thesis reedition (1967), Inst. Nacional Pesca Centro Reg. Invest. Pesqueras, Mex., Contrib. Invest. Pesquera, Doc. Técnico 7, $40 \mathrm{p}$.

J. C. Espinoza, and F. Ramírez. 1999. Exploratory and experimental fishing of octopus with Japanese traps in the continental shelf of Yucatan. Oceánides 13-14(21):39-46.

Yajima, S., and S. Mitsugi. 1975. Drawings of fishing gears for squid and octopus. Jpn. Mar Fish. Resour. Res. Cent. Rep. 5:65-78. 